\title{
Indigenous Knowledge Used in Breeding and Management of Capra hircus Populations in Kajiado and Makueni Counties, Kenya
}

\author{
Okello George Otieno, Joseph Owino Junga, M. S. Badamana, Joshua O. Amimo \\ Department Name of Animal production, University of Nairobi, Nairobi, Kenya \\ Email:padmo07@yahoo.com, okello.george014@gmail.com
}

Received 12 August 2015; accepted 27 September 2015; published 30 September 2015

Copyright (C) 2015 by authors and Scientific Research Publishing Inc.

This work is licensed under the Creative Commons Attribution International License (CC BY). http://creativecommons.org/licenses/by/4.0/

\section{Abstract}

The aim of this project was to study indigenous breeding practices used in management of Capra hircus (Galla and Small East African goats) populations in Kajiado County in Rift valley province and Makueni County in Eastern province. Data were obtained through a field survey using questionnaires (Appendix I) and personal observations between $1^{\text {st }}$ September, 2013 and $2^{\text {nd }}$ December, 2013. This study covered key characteristics of goats production and areas of goat breeding, such as general farm details, number of goats, main activities of the farmers, farming types, breeds, flock structure, feeding, housing, catastrophes, selection, mating systems, breeding systems, average age at parturition, breeding problems, and the importance of goats. Results showed that the average number of goats in Kajiado was $100.65 \pm$ std 49.88 while in Makueni it was $12.28 \pm$ std 6.46. The main activity of the people interviewed was farming as 58 people $(96.67 \%)$ in Kajiado and 42 people $(61.60 \%)$ chose farming as their main activity because this was their main source of livelihood. Flocks were dominated by breeding females at a mean of $39.06 \pm$ std 16.75 in Kajiado and a mean of $5.62 \pm$ std 3.50 in Makueni because females were kept to reproduce to increase the size of the flock and the males were kept majorly for cash and only one or two were left to reproduce with the females. Drought was the major catastrophe as it killed an average number of goats of $6.33 \pm$ std 4.36. Pneumonia and diarrhoea were the major diseases according to 28 farmers (46.66\%) in Kajiado and 31 farmers $(51.66 \%)$ in Makueni. Ticks and fleas were the major parasites according to 42 farmers (70\%) in Kajiado and 4 farmers (63.34\%) in Makueni. Treatment was mostly done by the farmers individually as 54 farmers $(90 \%)$ in Kajiado and 46 farmers (76.67\%) in Makueni treated the animals by themselves. This was so because it was either not easy to get a veterinarian or expensive for them to hire veterinarian doctors. Some farmers used traditional medicine like mavuavui; Steganotaenia araliacea was used to treat pneumonia. Farmers also devised feeding methods during drought as 48 farmers $(\mathbf{8 0 . 0 0 \%})$ in Kajiado and 23 farmers $(38.33 \%)$ in Makueni cut leaves from up trees to feed the goats. When doing selection of breed, 58 farmers $(96.67 \%)$ and 57 farmers (95\%) considered large body size and drought resis- 
tance respectively in Kajiado. The farmers in Makueni considered age and drought resistance at equal chances of 59 farmers $(\mathbf{9 8 . 3 3 \%})$. The main mating system was naturally uncontrolled as 113 farmers (95.17\%) of the overall 120 farmers interviewed in Kajiado and Makueni chose this as the main mating method. The major breeding system was pure breeding at 85 farmers $(70.83 \%)$. The average age at parturition of the goats was $1.435 \pm 0.125$ years in Kajiado and $1.44 \pm 0.121$ years in Makueni. Abortion was the major breeding problem because it was caused by environmental stressors like drought and diseases as 54 farmers (93.92\%) in Kajiado and 55 farmers (95.66\%) claimed that it was a problem. Goats were majorly kept for cash $(100 \%)$ and meat $(100 \%)$ in Kajiado and for cash $(100 \%)$ and dowry $(100 \%)$ in Makueni. In conclusion, the study showed that crossbreeding was encouraged by mating that occurred at the markets, water points, free ranging feeding method, pastoralism due to drought, selection methods and translocation of female goats from Makueni County to be mated with the males in Kajiado County. Environmental problems like drought and diseases caused several deaths and reduced the level of existing gene pool of the goats.

\section{Keywords}

Indigenous Knowledge, Breeding, Management, Capra Hircus, Kajiado and Makueni Counties

\section{General Introduction}

\subsection{Background}

\subsubsection{Indigenous Knowledge and Capra hircus}

Indigenous knowledge is the knowledge that is unique to a particular community. This knowledge helps in conservation and disaster preparedness. Local goats in Kenya have been scantily described when we consider indigenous knowledge based on conservation. There is a threat of loss of unique genotypes and loss of adaptation due to new practices, for example, crossbreeding with exotic breeds. Adaptability to certain terrain and disease resistance through indiscriminate crossbreeding has seriously reduced [1].

In Kenya the classification of the local goats based on phenotype/morphology identifies three breeds: Small East African (SEA) goats, the Galla and crosses of SEA and the Galla [1]. Galla goats are indigenous to the north areas of Kenya. They are also known as the Boran or Somali goat.

The Small East African goat is one of the most successful domestic goat breeds for the semi-arid lands. They are found all over East Africa from the arid land to urban areas. They are kept mainly for their meat, as milk production usually is only enough for the one single kid. They have a potential for selection and are useful breeding stocks for upgrading breeding. In their present unimproved form, their greatest advantage is the ability to survive in almost any environment [2].

Local animals are more resistant to local diseases than crossbreeds or exotic breeds and can survive in harsh conditions of drought and little food compared with the exotic ones or their crosses, i.e. the smooth coats of Boran cattle protect them from ticks [3].

\subsubsection{Problem Statement}

The ASAL regions constituted $76 \%$ of cattle, sheep and goats in Kenya [1]. The pastoral communities in these regions relied on indigenous livestock for food, social obligations and economic activities. Goats in ASAL regions form the integral part of fragile livelihood systems. Their inherent characteristics, such as resistance to dehydration and diseases, preference for browse and wide ranging feeding habits, enable them to thrive well in regions that receive less than $750 \mathrm{~mm}$ of rain fall [4]. However, there is scanty information on indigenous knowledge used in breeding of these goats. In other words, what do the local people living in the ASAL regions believe to be good animals? What traits do they consider? And which breeding systems do they prefer and why? Which skills do they use to keep these animals in the ASAL areas? We should conserve the good genes of the local goats that are able to strive and survive in the ASAL regions so that Kenya does not lose ground on holding well onto its economy and also ensure availability of enough meat. Before embarking on the conservation measures, a study on breeding practices and objectives and how these have been influenced by indigenous 
knowledge is important. Kisiangani noted that as a result of up-grading the local breeds for improved production in Kenya, there was loss of valuable indigenous genetic diversity. There was a need to reverse this trend and he made the following recommendation: documentation of indigenous knowledge on livestock breeds and breeding practices in the different communities in Kenya [5].

\subsubsection{Objective}

The aim was to determine communities' breeding systems, practices and objectives on the Galla and SEA goats and link these to the indigenous knowledge of these communities living in Kajiado and Makueni Counties.

\subsubsection{Research Question}

What indigenous knowledge do communities living Kajiado and Makueni apply when breeding the local goats?

\section{Materials and Methods}

\subsection{Study Areas}

This research was conducted in two Counties namely; Makueni and Kajiado. The study areas were chosen based on previous formal field surveys carried out for characterizing goat production systems, production and reproduction performances [6].

Makueni County (formerly Makueni District) (Figure 1) is in the former Eastern Province of Kenya. It is dominated by the Kamba community. Its capital and largest town is Wote. The County is bordered by Kajiado County to the west, Machakos County to the north. Kitui County to the East and Taita Taveta County to the south. The County covers an area of $8008.9 \mathrm{~km}^{2}$, out of which 474.1 square kilometres form the Tsavo West National Park and 724.3 square kilometres form the Chyulu Game Reserve. The hilly parts of the County receive

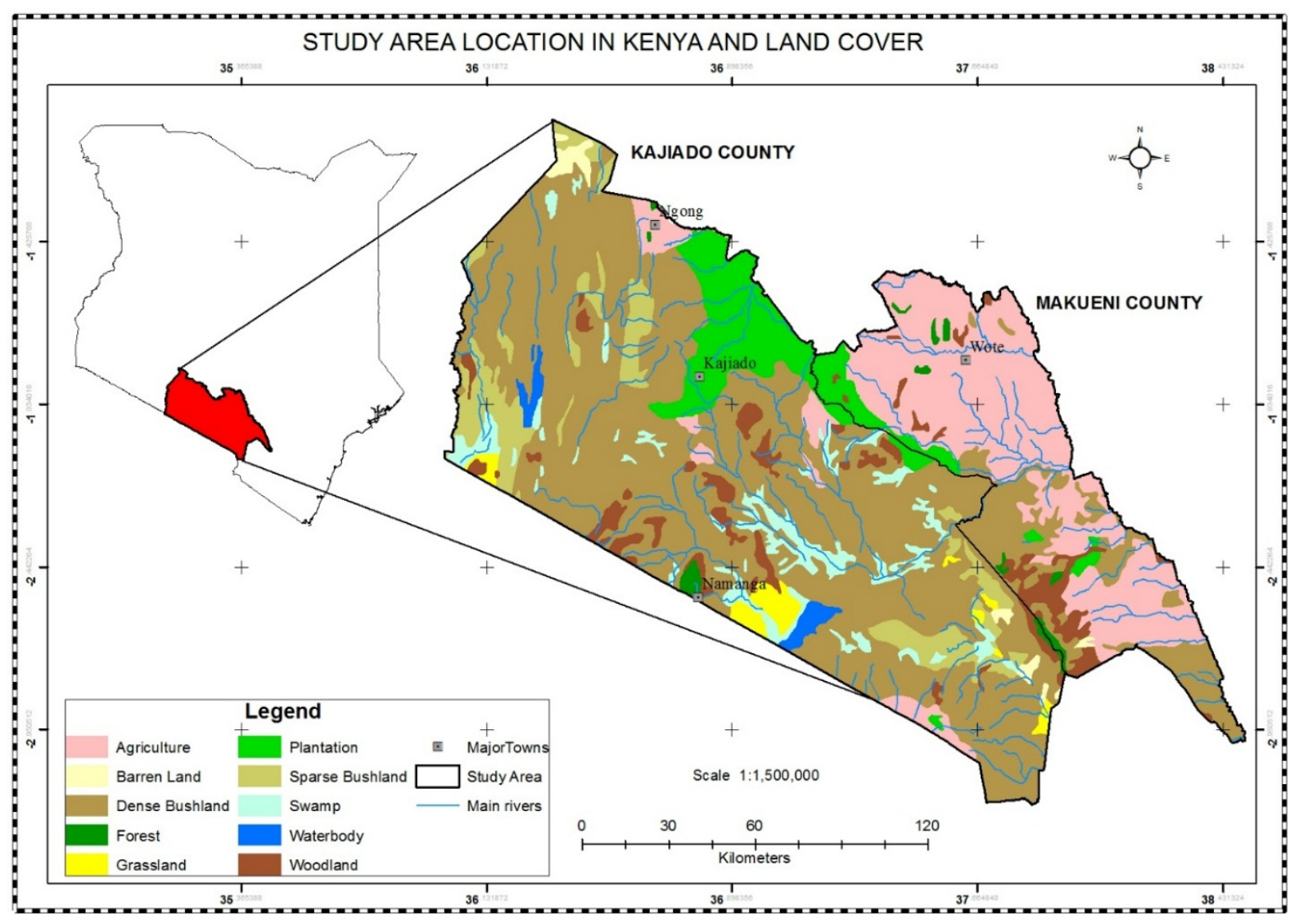

Figure 1. Study area location in Kenya and land cover. 


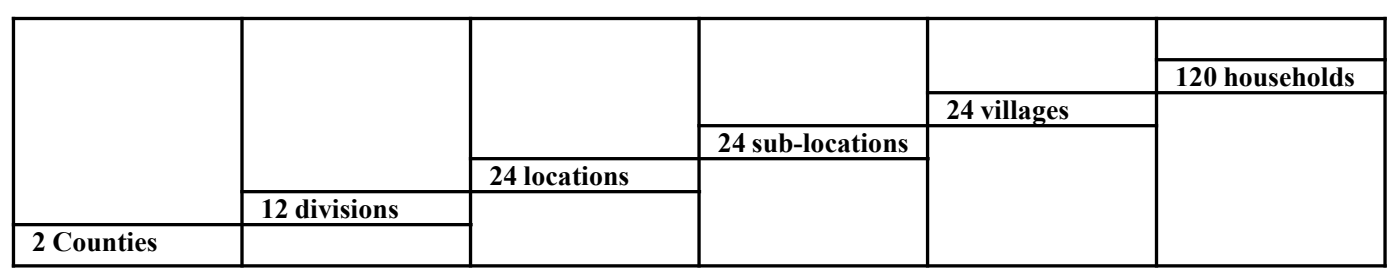

Figure 2. The flow chart showing multistage sampling procedure used.

800 to $1200 \mathrm{~mm}$ of rainfall per year. The rest of the district receives less rainfall at about $500 \mathrm{~mm}$ per annum. The high temperature experienced in the low-lying areas. Because of this pattern of rainfall, Makueni is classified as both arid and semi-arid land [7].

Kajiado County (Figure 1) is in the former Rift Valley Province of Kenya. The communities living in this County are the Maasai. It has an area of $21,903 \mathrm{~km}^{2}$. The County borders Nairobi city and extends to the Kenya-Tanzania border further south [8]. The southern parts of Kajiado receive $300 \mathrm{~mm}$ annual rainfall while the Northern parts receive $550 \mathrm{~mm}$ annual rainfall because of this Kajiado is classified as an arid land [9].

\subsection{Sampling and Administration of Questionnaire}

A total of 120 questionnaires were used in this study as shown in multistaged sampling procedure in Figure 2 with the 120 households representing total number of questionnaires. Focus group discussions was held with livestock keepers and knowledgeable key informants for generating general information regarding the history of the various goat types, special distinguished features of the targeted goats, production systems, and knowledge on the husbandry practices, challenges and opportunities of indigenous goats.

\subsection{Statistical Data Analyses and Processing}

The data collected were entered in excel and later exported to the statistical package (SAS V 9.0) for analysis. Different models in the SAS software were used to analyse the data. Descriptive statistics (central tendencies and dispersion measures) was used to describe the average numbers of goats, breeding practices, goat housing and equipment used by the farmers in goat production, goat feeds and feeding practices, goat diseases, uses of goats and marketing and farmer suggested interventions for the identified constraints using the model ; proc means $\mathrm{N}$ mean std max and min.

Frequencies were done using proc freq model in the SAS system software. Chi-square and fisher's test was also used to find significant effects of variables at $\mathrm{p}<0.005$ [10]. Univariate analysis graph was drawn using SAS software using proc univariate data.

\section{Results}

\subsection{The Distribution of the Socio-Economic Characteristics in Kajiado and Makueni}

The average family size for the interviewed households was 5.75 in Kajiado and 5.55 in Makueni shown in Table 1. Their ages ranged between 22 years and 67 year. Of the 60 farmers who were interviewed per County, 42 $(70.00 \%)$ were males and $18(30.00 \%)$ were females in Kajiado while $53(88.33 \%)$ were males and $7(11.67 \%)$ were females in Makueni. Majority of the flocks were owned by the family heads, 50 (83.33\%) in Kajiado and $58(96.67 \%)$ in Makueni. Farming was chosen as the main activity by the majority of the farmers at 58 farmers $(96.67 \%)$ in Kajiado and 42 farmers $(70.00 \%)$ in Makueni. Police and business were equal at 1 farmer (1.67\%) in Kajiado. In Makueni, the number of people who chose both farming and business came second at 11 farmers (18.33\%), Police and business came third at $4(6.67 \%)$ and fourth $3(5.00 \%)$ respectively. In Kajiado 54 interviewees $(90.00 \%)$ attained primary education, $4(6.66 \%)$ reached secondary school level and $2(3.34 \%)$ managed post-secondary school. In Makueni, 34 farmers (56.66\%) attained primary school, 23 farmer reached secondary and 3 farmers managed post-secondary school level. The type of land ownership was such that in Kajiado 34 farmers (56.67\%) managed their land under individual ownership while 26 farmers (43.33\%) managed their land in communal farming system and in Makueni 56 farmers (93.33\%) managed their land under individual ownership while 4 farmers (6.67\%) under communal land ownership. Semi-commercial and pastoralism 
Table 1. The distribution of the socio-economic characteristics in Kajiado and Makueni.

\begin{tabular}{|c|c|c|c|c|c|}
\hline \multirow{2}{*}{ Factor } & \multirow{2}{*}{ Variable } & \multicolumn{2}{|c|}{ Kajiado } & \multicolumn{2}{|c|}{ Makueni } \\
\hline & & $\mathbf{N}$ (mean) & $\%$ respondents & $\mathbf{N}$ (mean) & $\%$ respondents \\
\hline Family size & & $(5.75)$ & & $(5.55)$ & \\
\hline \multirow{2}{*}{ Gender } & Male & 42 & 70.00 & 53 & 88.33 \\
\hline & Female & 18 & 30.00 & 7 & 11.67 \\
\hline \multirow{3}{*}{ Flock owner } & Father & 50 & 83.33 & 58 & 96.67 \\
\hline & Mother & 5 & 8.33 & 2 & 3.33 \\
\hline & Children & 5 & 8.33 & 0 & 0.00 \\
\hline \multirow{3}{*}{ Manager } & Father & 27 & 45.00 & 49 & 81.67 \\
\hline & Mother & 25 & 41.67 & 1 & 1.67 \\
\hline & Children & 8 & 13.33 & 10 & 16.67 \\
\hline \multirow{7}{*}{ Main activity } & Farming & 58 & 96.67 & 42 & 70.00 \\
\hline & Police & 1 & 1.67 & 0 & 0.00 \\
\hline & Business & 1 & 1.67 & 0 & 0.00 \\
\hline & Teaching & 0 & 0.00 & 4 & 6.67 \\
\hline & Farming and business & 0 & 0.00 & 11 & 18.33 \\
\hline & Mechanics & 0 & 0.00 & 1 & 1.67 \\
\hline & Pastors & 0 & 0.00 & 2 & 3.33 \\
\hline \multirow{3}{*}{ Education } & Primary & 54 & 90 & 34 & 56.66 \\
\hline & Secondary & 4 & 6.66 & 23 & 38.34 \\
\hline & Post-sec. & 2 & 3.34 & 3 & 5.00 \\
\hline \multirow{2}{*}{ Land ownership } & Individual & 34 & 56.67 & 56 & 93.33 \\
\hline & Communal & 26 & 43.33 & 4 & 6.67 \\
\hline \multirow{3}{*}{ Farming type } & Pastoralism & 23 & 38.34 & 3 & 5.00 \\
\hline & Semi-commercial & 37 & 61.66 & 3 & 5.00 \\
\hline & Mixed farming & 0 & 0.00 & 54 & 90 \\
\hline
\end{tabular}

were the main types of farming in Kajiado at 37(61.66\%) and 23 (38.34\%) respectively. In Makueni, mixed farming was the main farming type at $(90.00 \%)$ and pastoralism and semi-commercial farming were equal at $5 \%$ each.

\subsection{Flock Structure and Average Number of Goats in Kajiado and Makueni}

Table 2 shows that the mean number of goats in Kajiado was $100.65 \pm$ std 49.88 goats and in Makueni the mean was $12.28 \pm$ std 6.46 goats. Flocks were dominated by the breeding females at mean of $41.78 \pm$ std 21.41 in Kajiado and $5.46 \pm$ std 3.34 in Makueni while the weaned males came second in Kajiado at $41.43 \pm$ std 21.63 and female kids in Makueni were second at $1.96 \pm$ std 1.90. The breeding bucks came last at a mean of $1.06 \pm 0.25$ in Kajiado and in Makueni, male weaners with 2 testicles came last at $0.61 \pm$ std 0.84 . There were no male weaners with 1 testicle, male kids with 1 testicle and no male adults with 1 testicle.

Figure 3 and Figure 4 shows the univariate description of the number of goats in Kajiado and Makueni. The coefficient of variation (CV) in Makueni was higher than that of Kajiado as the CV in Makueni was 52.66 while in Kajiado it was 49.56.

\subsection{Management Methods in Kajiado and Makueni}

The best feeding method in Kajiado was free range from the response of 55 farmers and both free range and tethering came second. Tethering was ranked first in Makueni with 33 farmers chose it as the best feeding method, 15 farmers did both free range tethering and 12 farmers did free range alone. The best housing type was by 
building goats houses using wood and thorn in Kajiado and mud house was the best house type used for goats in Makueni.

Table 2. Flock structure and average number of goats in kajiado and makueni.

\begin{tabular}{|c|c|c|c|c|c|c|}
\hline \multicolumn{4}{|c|}{ Kajiado } & \multicolumn{3}{|c|}{ Makueni } \\
\hline \multicolumn{7}{|c|}{ Average no. of goats } \\
\hline $\mathbf{N}$ & Mean & & SD & $\mathbf{N}$ & Mean & SD \\
\hline 6039 & 100.65 & & 49.88 & 737 & 12.28 & 6.46 \\
\hline \multirow[t]{2}{*}{ structure } & \multicolumn{3}{|c|}{ Kajiado } & \multicolumn{3}{|c|}{ Makueni } \\
\hline & $\mathrm{N}$ & Mean & SD & $\mathrm{N}$ & Mean & SDS \\
\hline Female kids & 513 & 8.55 & 7.68 & 118 & 1.96 & 1.90 \\
\hline Male kids & 393 & 6.56 & 5.99 & 89 & 1.48 & 1.56 \\
\hline Weaned females & 859 & 14.31 & 10.48 & 75 & 1.25 & 1.72 \\
\hline Weaned males & 2486 & 41.43 & 21.63 & 43 & 0.71 & 0.94 \\
\hline Weaners with 1 testicle & 0 & 0.00 & 0.00 & 0 & 0.00 & 0.00 \\
\hline Castrate weaners & 648 & 10.80 & 9.12 & 0 & 0.00 & 0.00 \\
\hline Weaners with 2 testicles & 228 & 3.80 & 4.91 & 37 & 0.61 & 0.84 \\
\hline Kids with 1 testicle & 0 & 0.00 & 0.00 & 0 & 0.00 & 0.00 \\
\hline Kids with 2 testicle & 379 & 6.31 & 5.94 & 80 & 1.33 & 1.56 \\
\hline Adults with1 testicle & 0 & 0.00 & 0.00 & 0 & 0.00 & 0.00 \\
\hline Adults with 2 testicle & 64 & 1.06 & 0.25 & 70 & 1.16 & 0.37 \\
\hline Castrate male adults & 1013 & 16.88 & 13.40 & 0 & 0.00 & 0.00 \\
\hline Mature males & 1077 & 17.95 & 13.45 & 70 & 1.16 & 0.37 \\
\hline Breeding females & 2507 & 41.78 & 21.41 & 328 & 5.46 & 3.34 \\
\hline Breeding bucks & 64 & 1.06 & 0.25 & 70 & 1.16 & 0.37 \\
\hline
\end{tabular}

Goat Data

cossry

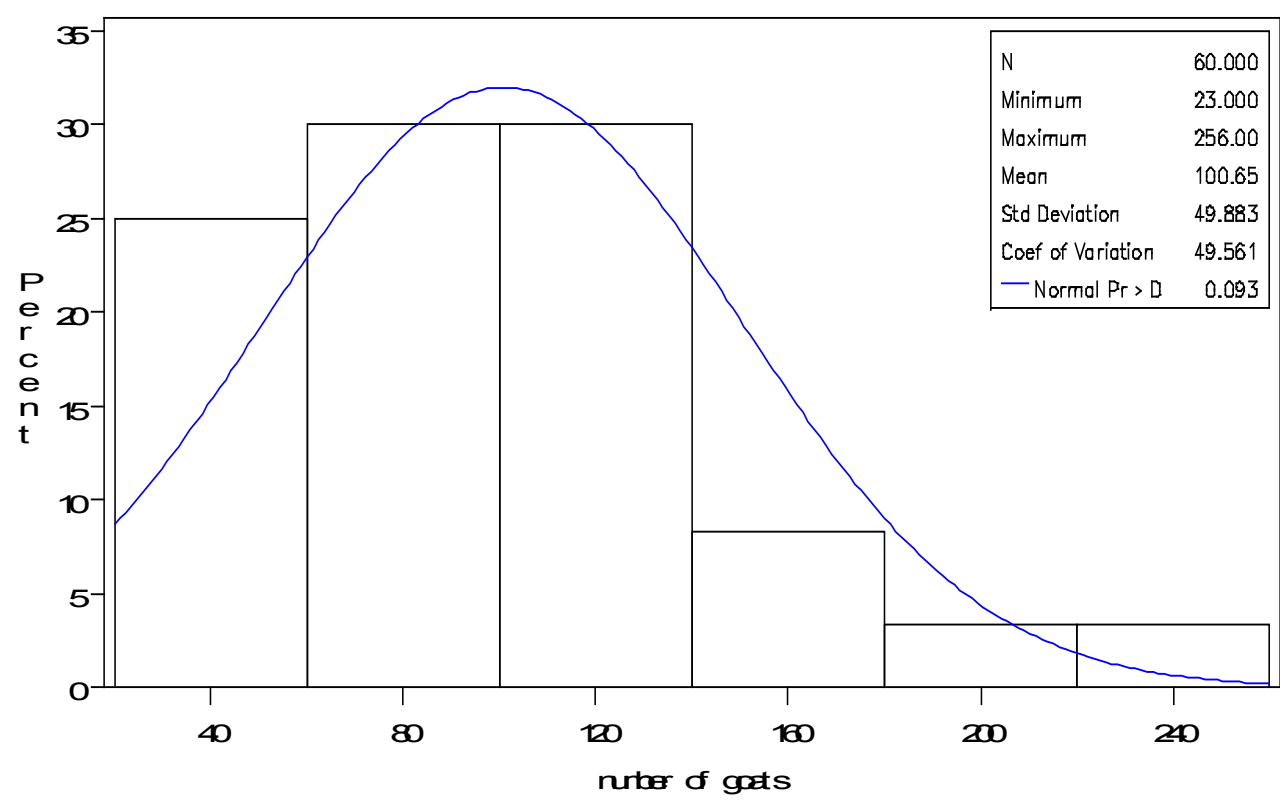

Figure 3. Univariate analysis of the number of goats in Kajiado County. 


\section{Goat Data}

coove

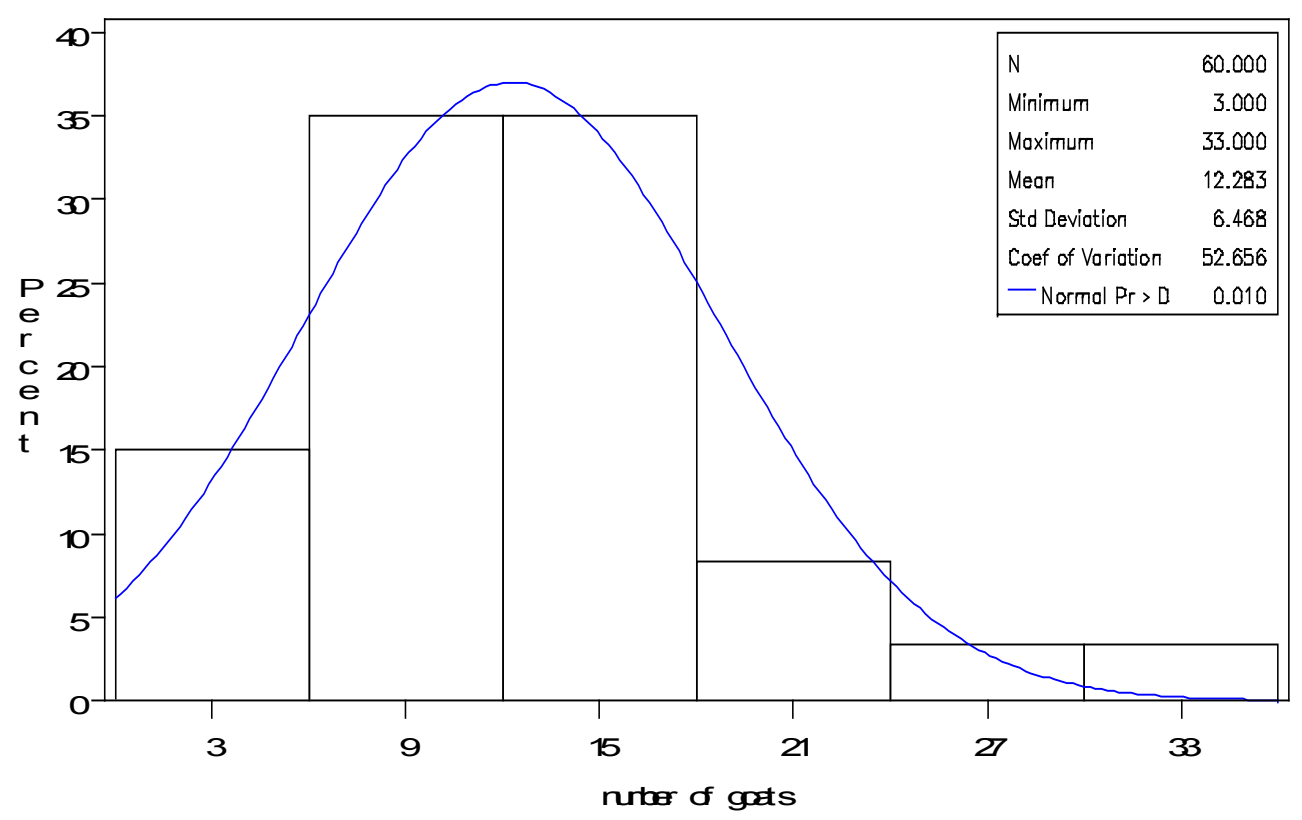

Figure 4. Univariate analysis of the number of goats in Makueni County.

\subsection{Catastrophes in Goat Management in Kajiado and Makueni Counties}

Drought caused the highest effects with a mean of $1.87 \pm 1.64$ animals lost whenever there was drought for both the Counties. Diseases came second at a mean loss of $0.29 \pm 0.59$ goats. Rustling was ranked last at a mean loss of $0.08 \pm 0.28$ animals. One farmer in Namanga lost 3 goats which were predated on by a leopard.

\subsection{Animal Health in Kajiado and Makueni Counties}

Pneumonia and diarrhoea was ranked first while pneumonia alone was second among the diseases mentioned by the farmers to be causing a lot of problems in the two Counties. Pneumonia and rabies was ranked third in Kajiado while rabies alone was ranked last. Rabies was ranked third in Makueni while pneumonia and rabies was ranked last. Of the dangerous parasites, ticks and fleas were ranked first while tick alone came second in the two Counties. Most of the farmers did individual treatment of the goats, followed by private vets and lastly government vets.

\subsection{Ethno-Medicine in Kajiado and Makueni}

Traditional medicines used in the treatment of goats are indicated in Table 10. The most dangerous diseases in the two Counties like pneumonia was treated using mavuavui, mukomole mukenia, and mwezenze. Stomach problem was treated using uswe while retained placenta was removed by giving goats a handful of maize. There was no herbal drug to cure rabies.

\subsection{Management of Goats during Drought}

The major water sources in Kajiado were government constructed water points and pipeline while rivers, stream, and dams were used by a few people. The major water sources in Makueni were stream, river and government constructed water points while wells, and pipeline, were used by a few people and one person used dam. Water was always available and reliable (Table 3). The methods of food provision was such that most farmers in Kajiado cut leaves from up the tree to feed the leaves and only a few people pick leaves, cut and buy commercial feeds and just a very small portion pick the leaves from the ground. Most farmers in Makueni pick leaves and also do both cutting and picking of leaves. A few people cut leaves and also collect, cut and buy leaves. 


\subsection{Factors Considered When Selecting Breed in Kajiado and Makueni Counties}

The farmers in Kajiado considered body size then drought resistance, colour of fur, age, disease resistance, milk production, physical appearance, conception rate, docility, growth rate, posture and gait in the order (Table 4). Most farmers in Makueni considered age and drought resistance then disease resistance, milk production, physical appearance, conception rate, growth rate, docility, body size and posture and gait in the order.

\subsection{Factors Considered When Selecting Females and Males in Kajiado and Makueni}

Females were selected by considering mothering ability then body size, coat colour was third and body structure was last (Table 5). Most farmers considered, age, body size, disease resistance, reduction of inbreeding, physical appearance and improvements in the order when selecting males.

\subsection{Importance of Goats in Kajiado and Makueni}

All the farmers kept goats for cash. All the farmers in Kajiado kept goats for blood while most farmers kept goats

Table 3. Goat management during drought in Kajiado and Makueni.

\begin{tabular}{|c|c|c|c|c|c|c|}
\hline \multirow{2}{*}{ Management } & \multicolumn{3}{|c|}{ Kajiado } & \multicolumn{3}{|c|}{ Makueni } \\
\hline & $\mathbf{N}$ & $\%$ respondents & Rank & $\mathbf{N}$ & $\%$ respondents & Rank \\
\hline \multicolumn{7}{|l|}{ Water source } \\
\hline Govt constructed water points & 33 & 55 & 1 & 11 & 18.33 & 3 \\
\hline Pipeline & 13 & 21.67 & 2 & 7 & 11.67 & 5 \\
\hline River & 6 & 10.00 & 3 & 13 & 21.67 & 2 \\
\hline Stream & 6 & 10.00 & 4 & 19 & 31.67 & 1 \\
\hline Dam & 2 & 3.33 & 5 & 1 & 1.67 & 6 \\
\hline well & - & - & - & 9 & 15.00 & 4 \\
\hline Water availability/reliability & 60 & 100 & & 60 & 100 & \\
\hline \multicolumn{7}{|l|}{ Food provision } \\
\hline Cut leaves from trees & 48 & 80.00 & 1 & 8 & 13.33 & 3 \\
\hline Collect and cut leaves and buy commercial feeds & 9 & 15.00 & 2 & 7 & 11.67 & 4 \\
\hline Collect/pick leaves & 3 & 5.00 & 3 & 23 & 38.33 & 1 \\
\hline Collect and cut leaves & 0 & 0.00 & - & 22 & 36.67 & 2 \\
\hline
\end{tabular}

Table 4. Factors considered when selecting breed in Kajiado and Makueni.

\begin{tabular}{|c|c|c|c|c|c|c|}
\hline \multirow{2}{*}{ Factor } & \multicolumn{3}{|c|}{ Kajiado } & \multicolumn{3}{|c|}{ Makueni } \\
\hline & No. of respondents & Percent & Rank & No. of respondents & Percent & Rank \\
\hline Body size & 58 & 96.67 & 1 & 5 & 8.33 & 11 \\
\hline Drought resistance & 57 & 95.00 & 2 & 59 & 98.33 & 1 \\
\hline Colour of fur & 57 & 95.00 & 3 & 11 & 18.33 & 8 \\
\hline Age & 54 & 90.00 & 4 & 59 & 98.33 & 1 \\
\hline Disease resistance & 52 & 86.67 & 5 & 52 & 86.67 & 3 \\
\hline Milk production & 49 & 81.67 & 6 & 28 & 46.67 & 4 \\
\hline Physical appearance & 43 & 71.67 & 7 & 26 & 43.33 & 5 \\
\hline Conception rate & 7 & 11.67 & 8 & 21 & 35.00 & 6 \\
\hline Docility & 7 & 11.67 & 9 & 6 & 10.00 & 9 \\
\hline Posture and gait & 4 & 6.67 & 10 & 5 & 8.83 & 11 \\
\hline Growth rate & 2 & 3.33 & 11 & 14 & 23.33 & 7 \\
\hline
\end{tabular}


Table 5. Factors considered when selecting females and males in Kajiado and Makueni.

\begin{tabular}{ccc}
\hline & Females & \\
\hline Factor & No. of respondents & Percent \\
Mothering ability & 101 & 84.17 \\
Size & 80 & 66.67 \\
Colour of fur & 59 & 49.17 \\
Body structure & 17 & 14.17 \\
\hline & Males & Percent \\
\hline Factor & No. of respondents & 91.67 \\
Age & 110 & 90.83 \\
Body size & 109 & 90.00 \\
Disease resistance & 108 & 64.17 \\
Reduce inbreeding & 77 & 39.17 \\
Physical appearance & 47 & 35.83 \\
\hline Improvement & 43 & \\
\hline
\end{tabular}

for chevon, dowry, milk and circumcision shown in (Table 10). A few farmers kept the goats for skin, manure, gift, church functions and for naming children. All farmers in Makueni kept goats for dowry and majority kept the goats for manure, chevon, milk and blood. A few farmers kept the goats for circumcision, skin, gifts and church.

\section{Discussions}

\subsection{The Distribution of the Socio-Economic Characteristics in Kajiado and Makueni}

The average number of family members was 5.75 and ranged between 2 - 10 members in Kajiado while it was an average of 5.55 and a range of between 2 - 11 people in Makueni (Table 1). This means that goat production supported a higher number of family members in Kajiado who practiced more pastoralism than Makueni. Tekleyohannes reported that goat's production in South Omo zone supported larger family size of the pastoral communities on average than the agro-pastoral regions [11].

Out of the 60 farmers interviewed in Kajiado 42 farmers were males while 18 were females. In Makueni, 53 were males and 7 were female farmers (Table 1). A chi square test reveals a significant difference in gender of the farmers who were interviewed $\mathrm{p}<0.001$. These meant that majority males associated themselves with farming of goats than females.

In most of the families, goats were owned by the family heads (Table 1). Of all the flocks sampled in Kajiado, 50 flocks $(83.33 \%)$ were owned by male family heads. Out of the 60 flocks sampled in Makueni, 58 flocks $(96.67 \%)$ were owned by the male family heads. There was gender bias in flock ownership as it was evident that most of the flocks were owned by the male family heads. I agreed with Stroebel's finding that in Kenya generally the ownership of animal flocks were male dominated [12].

Of all the farmers interviewed per County, 49 famers (81.67\%) in Makueni and 27 farmers (45.00) in Kajiado were household heads as overall managers. The number of women who managed the goats was $1(1.67 \%)$ in Makueni, while in Kajiado they were 25 women (41.67\%). The number of children who did the same were 10 (16.67) in Makueni and 8 children (13.33\%) in Kajiado (Table 1). These means that the duties concerning management were mostly shared among family members. These family members drive the animals out in the morning to feed, bring them back to shelter in the evening, they provide water, look for treatment means whenever the animals are sick, provide special attention in terms of feeding the goats during drought. The duty of milking was shared among family members except that milk processing was left for the women both in Kajiado and Makueni. Slaughtering of goats was done by the male family members. According to Stroebel management of animals in Kenya was done by men and milking was done by the mother totally different from the finding in this research. Stroebel's research and my research are same in that both found that milk processing was done by the mothers [12]. Oluka found that women participated in livestock management activities and 
were mainly involved in tethering; kraal cleaning; and watering of the animals. His findings were same to my results for Kajiado and Makueni since the management were majorly shared between family members [13].

Farming was the main activity according to 58 farmers (96.67\%) in Kajiado, 1 farmer (1.67\%) was a policeman and 1 farmer (1.67) was a business person. Of all the farmers interviewed in Makueni, 42 farmers (70.00\%) did farming as their main activity, 4 farmers $(6.67 \%)$ were teachers, 11 people $(18.33 \%)$ were farmers and business people, 1 farmer (1.67) was a mechanic and 2 farmers (3.33\%) were pastors (Table 1). Chi-square test (Table 1) showed that there was a significant difference in the main activity of the farmers in the two Counties $p$ $<0.001$. This clearly indicates that farming was the major source of livelihood in the two Counties with Kajiado recording highest percentage of (96.67\%) than Makueni at (70.00\%).

The education of the farmers were such that 34 farmers (56.66\%) in Makueni and 54 farmers $(90.00 \%)$ in Kajiado attained primary education, 23 farmers (38.33\%) in Makueni and 4 farmers $(6.67 \%)$ in Kajiado attained secondary school education. There were 4 farmers (6.67\%) in Makueni and 2 farmers (3.33\%) in Kajiado who managed to post-secondary education. A chi-square test $(\mathrm{p}<0.001)$ and a likelihood ratio $(\mathrm{p}<0.001)$ revealed significant difference in education level of the farmers in the two Counties. These results indicate that most farmers in Makueni attained secondary education than the farmers in Kajiado. Goat management does not only need formal education only in order to bring prosperity but including indigenous knowledge is also important. This is evidence in this research where a few farmers in Kajiado had not attained the basic secondary education but managed many goats than the farmers in Makueni County where many farmers had the basic secondary education. Education had also created awareness to various agricultural developmental issues or programmes that support agriculture in Makueni; for example Micro Enterprise Support Programme Trust (MEST) based in Wote division. This result could be compared to Ole Kwalla's who noted that if a Maasai farmer gets educated, can't it be argued that schooling improve his ranching? The actual rate of return to investment agriculture is related to education level of the farmer involved. He went ahead to say that a large majority of Maasai had successfully resisted formal education for themselves and their children. The schools in pastoral areas were functioning for themselves and their children. Schools were kept alive for Maasai pastoral under - enrolled conditions, which would have closed them down in most other parts of Kenya. Their indecision made majority of children to go to school late in life and as a result of hold up (repetitions) to achieve district academic standards. They mature long before secondary and at this age the boys were required at home to provide needed livestock labour hence drop out of school [14].

\section{Land Ownership, Farming Types and Dominant Goat Breed in Kajiado And Makueni Counties}

The type of land ownership in Kajiado and Makueni were different (Table 1). Land was majorly individually owned (93.33\%) in Makueni. Nearly half of the land was communally owned (43.33\%) in Kajiado. The type of land ownership and land use in Kajiado encouraged goats' production because there was no restriction about where to feed the goats. The vast available land was for livestock grazing. According to Chris $97 \%$ of the land in Turkana district was communally owned, only a very small portion was privately owned [15]. This was different from Kajiado when we consider the percentage of land that was communally owned. The farmers in Kajiado practiced pastoralism because large part of land was still communally owned as opposed to non-pastoral areas where land was majorly individually owned. Grandin found that traditionally there were eight sections in Kajiado district with mean size of $2275 \mathrm{~km}^{2}$, in 1985 there were 51 group ranches with mean size of $300 \mathrm{~km}^{2}$ and hundreds of individually owned ranches. Whereas early in the adjudication of Kajiado district large individual ranches were the prerogative of the elite; later as some people refused group ranches; their areas were individually adjudicated, but in smaller pieces. He also said that it seemed that land was still largely used communally in many of these areas [16]. This is same to the findings in this research.

Different farming types were used in Kajiado and Makueni Counties (Table 1) as 23 farmers (38.33\%) were pastoralists while 37 farmers $(61.67 \%)$ practiced semi-commercial types of farming in Kajiado. Three farmers $(5.00 \%)$ practiced pastoralism and another 3 farmers $(5.00 \%)$ practiced semi-commercial type of farming while 54 farmers $(90.00 \%)$ practiced mixed farming in Makueni. This clearly means that there was a lot of semicommercial farming and pastoralism in Kajiado. Pastoralism in Makueni was done by the Maasai farmers who crossed from Kajiado to graze their goats in Makueni County especially around Emali in Mbitini division (The border of Kajiado and Makueni County). Those who practiced pastoralism did it in search for pasture and not in search for water. The major type of farming in Makueni was mixed farming. Farmers in Makueni practiced mixed farming as a method of diversification to reduce risks of total loses in case of catastrophes like drought 
and also to get maize which is a staple food for the Kamba community living in this County. Crop production in Kajiado was done in Kimana where tomatoes were grown and Loitokitok where maize and beans were grown but none of the farmers interviewed claimed to own these farms. The farmers in Kajiado majorly kept livestock under semi-commercial and pastoralism and so rely majorly on livestock production. Chris found that many pastoralists in Turkana farmers moved long distances with their livestock. They moved to places where the host communities were accommodative and where there were abundant pastures and less animal diseases [15]. The difference between my research and Chris' research is that in my research, the farmers did not say that they considered places with less disease. The two researches found that the pastoralism was done in search of pasture nowadays and security was considered by all the farmers. Chris did not mention water as a cause of pastoralism same to this research where the farmers said that water was available and reliable in Kajiado and Makueni (Table 7). Kithama noted that in the lower part of Kibwezi district, migrations of cattle and camels enroute to Taita Taveta ranches from Tana river had been noted. The Maasai herdsmen had started moving their livestock to Chyulu and Tsavo National Parks. In addition to relocating their herds to Makueni County along the Mombasa road, this was the same to my research [17].

Out of the 180 goats sampled in Kajiado, 128 (71.11\%), were Galla goats and 52 (28.89\%) were SEA goats. A chi-square test showed that there was significant difference in the number of Galla and SEA goats $\mathrm{p}<0.001$. Out of the 180 goats sampled in Makueni, 111 (61.67\%) goats were SEA and 69 (38.33\%) were Galla goats and again chi-square test showed that there was a significant difference between the number of Galla goats and SEA goats in Makueni. $\mathrm{p}<0.001$. These results indicate that the Galla goat was the dominant goat breed in Kajiado while SEA goat was the dominant goat breed in Makueni. According to Coffey there were approximately 200 goat breeds in Kenya [18]. These included SEA and Galla goats. Ahuya noted that exotic dairy and meat goats were imported into Kenya starting in the 1950s and more rigorous in the 1970s and early 1980s [19]. In Kajiado and Makueni, only the Galla and the SEA goats were found. These were local goats that were able to survive in these two Counties because they were tolerant to environmental problems.

Even though the Galla goat breed was dominant in Kajiado and the SEA goat breed in Makueni, the two goat breeds were found in either of the Counties. This scenario was caused by the types of land ownership and the types of farming. Communal land ownership in Kajiado and pastoralism as type of farming encouraged cross-breeding between the two breeds. During pastoralism, goats meet and mate and different genes are expressed both for the Galla and the SEA goats.

\subsection{The Average Number of Goats per Household and Flock Structure in Kajiado and Makueni}

In Table 2, the mean number of the goats in Kajiado was $100.65 \pm$ std 49.88 goats. The mean number of goats in Makueni was $12.28 \pm$ std 6.46 goats. Univariate analysis in the normal distribution curve showed that in Kajiado the coefficient of variation (CV) was 49.56 and a range of 23 goats to 256 goats (Figure 3 ) while Makueni had a CV of 52.62 and a range of 3 goats (Figure 4). This means that the farmers in Kajiado produced more goats than the farmers in Makueni. This could also be attributed to land use. Most of the farmers in Makueni practiced mixed farming, that is, they kept goats and other domestic animals as well as growing of crops like mangoes, oranges, beans, maize, green grams, bananas and sorghum. The farmers in Kajiado majorly practiced livestock production whereby they kept goats and other domestic animals like cattle, sheep, donkeys except in Kimana where tomatoes were grown and Loitokitok where maize and beans were grown. The farmers in Kajiado therefore had a lot of land space to graze their animals than the farmers in Makueni. This encouraged free ranging system of feeding and made them keep many goats. These showed that pastoralists kept many goats compared to the farmers in non-pastoral communities. Even Chris found that the farmers in Southern part of Turkana district who were pastoralists kept flocks sizes of 20-50 goats while the Northern part kept $50-100$ goats [15]. Although the numbers were different but the point is pastoral communities kept many animals because this was the main source of livelihood. Kithama found that in Makueni each household had an average of 10 goats nearly the same to my research [17]. Tekleyohannes also noted had similar results that in Ethiopia pastoralists kept on average more goats than the agro-pastoralists areas; he reported a herd size of $66.7 \pm 54.2$ goats for pastoralists and $41.8 \pm 31.2$ goats for agro-pastoralists areas [11].

The flock structure consisted of female kids, male kids, weaned females, weaned males, mature females, and mature males, male weaners with two testicle, male castrate weaners, adult males with two testicles, male castrate adults, breeding females and breeding males in Kajiado (Table 2). There were no; males adults with one 
testicle, male kids with 1 testicle and castrate male weaners with one testicle as this type of castration whereby the one testis is removed and the other is left was not practiced. There were also no castrate kids. The average number of female adults was highest in both the two Counties by $41.78 \pm$ std 21.41 in Kajiado and $5.46 \pm 3.34$ in Makueni. The average number of castrate weaners was $10.80 \pm \operatorname{std} \pm 9.12$ in Kajiado and none of the weaned animals were castrated in Makueni. Castrate male adults were $16.88 \pm$ std 13.40 in Kajiado. None of the adult animals were castrated in Makueni. An average of $1.06 \pm$ std 0.25 of the goats were intact male adults with two testicles in Kajiado and 1.16 \pm std 0.37 in Makueni. Kosgey found that small holder farmers in Kenya owned an average of $2.6 \pm 3.5(\mathrm{SD})$ kids, $2.8 \pm 4.8$ weaners, $5.7 \pm 7.9$ adults - maximum of 16 kids, 21 weaners and 33 adults. While the pastoral farmers had $9.2 \pm 12.2$ kids, $8.5 \pm 11.4$ weaners, $23.1 \pm 31.5$ adults - maximum of 100 kids, 70 weaners and 200 adults [20]. Galvin found that herds typically consisted of $66 \%$ milk providing females, while neutered males were raised for meat consumption, traditional and market exchange [21]. Galvin's findings and this research are the same in that they found that the breeding females dominated the flocks. Kosgey's research put goat kids last in number very different from this research. Kosgey's difference can be explained in that the production of goats in Kenya as a whole might not be uniform. Some farmers in Kenya does not regard goat rearing as the main source of wealth. This gives a smaller average in comparison to research done where goat production is the main source of livelihood or part of livelihood. In my research female goats dominated the flocks because they were used to add the size of the flocks by breeding them. The males were majorly kept for cash and only one or two was left to breed with the females.

\subsection{Breeding of Goats in Kajiado and Makueni}

\subsubsection{Important Factors that Influence Choice of Breed of Goats}

The farmers in Kajiado County considered, adaptability, age and market value based on size: 57 farmers (95.00\%) considered drought resistance, 52 farmer $(86.67 \%)$ considered disease resistance whereby they selected the goats they knew would survive these problems; 58 (96.67\%) farmers considered big body sized goats, 57 farmers $(90.00 \%)$ considered white coloured goats, 54 farmers $(90.00 \%)$ considered young adults, 49 farmers $(81.67 \%)$ for milk production and 43 (71.67) farmers (Table 4) considered physical appearance are the factors considered for high market value. The farmers in Kajiado believed that a white coloured goat would fetch a lot of money than a black coloured goat if they were of the same size. White colour was also considered for heat tolerance since a white material reflects light and hence heat. Farmers in Makueni majorly considered adaptability and age, 59 farmers $(98.33 \%)$ considered drought resistance, 52 farmers $(86.67 \%)$ considered disease resistance for adaptability; 59 farmers $(98.33 \%)$ considered young adults for selection. The farmers preferred young adults for breeding. Tekleyohannes reported that the farmers in Hamer in South Omo zone 95\% of the farmers and in Bena-Tsemay $82 \%$ of the farmers valued adaptive traits of goats such as tolerance to drought and disease resistance above performance traits [11].

\subsubsection{Factors Considered When Replacing the Breeding Males and Females in Kajiado And Makueni}

Several factors were put into consideration when replacing the breeding males; age, body size and disease resistance were the main factors the farmers considered across the two Counties. Inbreeding was also another factor the farmers wanted to eradicate. Males were chosen by considering young adults with big body size, disease resistance, reducing inbreeding, physical appearance, and improvement (Table 5). Some farmers in Makueni translocated their female goats to Kajiado where there were males of big body size. Big body sized males were considered because their offsprings grew very fast and overpowered environmental problems in these regions. Offspring suffered most in case of the environmental problems; like drought and diseases like pneumonia and so most of them died. During drought they don't get enough milk from their mothers. Translocating the females helped reduced inbreeding and helped in genetic improvement. Tekleyohannes noted that the farmers in Ethiopia farmers chose breeding bucks based on body size, height, coat colour and performance history [11].

The best way of selecting female goats for the breeding of subsequent generations was to use the offspring of a successful nanny. By comparing the performance of both the parents and their kids the selection decision were made. The farmers believed that the offspring of a successful nanny would also be successful. Important traits that were considered in selection decisions included size, colour of fur and mothering ability (Table 5). Good mothering ability was the most important factor considered by 101 farmers $(84.17 \%)$ in Kajiado and Makueni 
while big body size was second and colour of fur came third where by farmers preferred white coloured females than black ones and this happened especially in Kajiado. Tekleyohannes also found that a higher percentage of farmers in Hamer in Ethiopia $71 \%$ considered good mothering ability, large body size, and conformation when selecting females for reproduction [11].

\subsubsection{Mating and Breeding Systems}

The major mating system used in the two Counties was natural uncontrolled mating since there were 113 farmers $(94.17 \%)$ who used this method. The rest of the farmers used natural controlled method. A chi-square test showed that there was a significant difference in the mating systems used $p<0.001$. The breeding male was left to mate with the females. If the number of females were many, then two males were left to mate with the females. Natural uncontrolled method was done to allow the goats to breed freely to increase the size of the flock. The farmers who practiced natural controlled breeding, did it to timing mating in June or July so that the young ones are born when there was plenty of food for the goats. There was a significant difference $p<0.001$ in the factors the farmers considered when they choose the mating system. Kosgey reported uncontrolled mating within the household's flock was predominant (an average of $42 \%$ ) for Small holder and $54 \%$ for pastoral farmers for goats. He also reported group mating, in which a group of does were left with one or more bucks to mate for a predetermined period [20]. His findings were similar to my findings in this research. The same results had also been reported by Semakula [22].

The farmers used either pure breeding or cross breeding of the Galla and SEA goats in Kajiado and Makueni Counties. Of the 120 farmers interviewed in the two Counties, 85 farmers $(70.83 \%)$ used pure breeding while 35 farmers (29.17\%) did cross breed the Galla and SEA. Two farmers said that pure Galla goats from Garissa County were sold in markets in the two Counties. Cross breeding with exotic breeds did not happen because the exotic breeds and their offspring could not adapt to the harsh environmental conditions. There was a significant difference in the choice of breeding system, chi-square $-p<0.001$. This means that the best system for breeding local goats in Kajiado and Makueni was pure breeding of two indigenous goat breeds. This result was similar Semakula who noted that in Uganda the main breeding system was pure indigenous breeding in a research done in Arua and Soroto districts [22].

\subsubsection{Average Age at First Parturition and Lifespan of the Goats}

Most the respondents said that parturition started at the age of between $1.2-1.5$ years and with a mean of 1.44 years for both the breeds. The farmers added that the lifespan was around $7-8$ years for both the SEA and the Galla goats. Kosgey reported that small holder farmers mated animals for the first time at about $10-11$ months meaning that kidding occurred at $15.5-16.5$ months. A slightly big range that he recorded was $9-12$ months first time mating in pastoral communities which meant that kidding occurred at $14.5-17.5$ months [20]. His findings were similar mine. This result means that local goats in Kajiado and Makueni late because of the stress conditions that interfere with the breeding conditions like during drought the males are weak and rarely mate with the females.

\subsubsection{Factors Affecting Goat Breeding in Kajiado and Makueni Counties}

1) Shared markets and translocation of goats

The shared markets like Emali, Makindu, Wote, Salama, Mtito Andei and Kibwezi and Simba encouraged cross breeding between the two goat breeds in the two Counties. In these markets any farmer sold or bought any type of breed of goat. This way the farmers in Kajiado bought SEA goats and the farmers in Makueni bought Galla goats and vice versa. Some goats mate at the market. The farmers in Makueni County translocated the SEA female goats to Kajiado County to get mated with the large male Galla goats.

2) Drought, diseases, livestock rustling and predation

The major catastrophes in Kajiado and Makueni were drought, diseases, livestock rustling and predation which caused losses and at the same time affected breeding. Drought was the most problematic as an average of $1.87 \pm$ std 1.64 goats died because of this, disease was second at a mean of $0.29 \pm$ std 0.59 while rustling was last at $0.08 \pm 0.28$ (Table 6). One farmer in Namanga lost 3 goats which were predated on by a leopard. Drought reduced population and flock sizes for various farmers. It caused feed to be less. These caused stress and reduced reproduction rate. The goats become thin and fetched little cash from the market. Milk output also reduced. Migrating with the animals to graze away from home to where they could get enough feed for the goats 
caused risks of being attacked by cattle rustlers, diseases and parasites and also caused cross-breeding of goats since different flocks of goats met and mated. Rustling caused loss of flocks and also conflicts and even loss of lives and market for goats. Goats were stolen from one County to another and this led to transfer of genes and hence encouraged cross-breeding. Chris found that in Turkana district the major catastrophes facing the farmers were drought, diseases and rustling. She similarly noted that pastoralists in Turkana district suffered from chronic insecurity, provoked by cattle raiding and the competition for access to water and grazing area. Chris went ahead to say that insecurity resulted into reduced access to market for sale of livestock [15]. Lukhele and Ramsey confirmed conflicts reduced the number of animals being farmed and loss of lives because of raids [23]. Convoy and Rangnekar was same in that they found drought as the major cause of deaths of goats but different because they noted that lack of feed came second. Rustling came third, diseases were put fourth while predation was last [24].

\subsubsection{Common Diseases and Parasites of Goats Recorded in Kajiado and Makueni}

Pneumonia (Maasai call it orkipei), rabies, diarrhoea were the major disease problems (Table 7) in the two Counties. A total of 22 farmers (37.66\%) in Kajiado said that pneumonia caused the greatest problem, 1 farmer $(1.67 \%)$, said rabies affected his flocks, 9 farmers $(15.00 \%)$ claimed for both pneumonia and rabies while 28 farmers $(46.67 \%)$ said both pneumonia and diarrhoea were the most dangerous diseases. A total of 27 farmers $(45.00 \%)$ in Makueni claimed for pneumonia (Kamba call it mavua), 2 farmers (3.33\%) said rabies interfered with their flocks and 31 farmers $(51.67 \%)$ claimed for both pneumonia and diarrhoea. Chi-square test $\mathrm{p}<0.05$ showed that there was a significant difference within the diseases causing the problems. This result was similar to Kosgey who said that pneumonia and diarrhoea was common among Kenyan pastoral communities though he did not mention rabies as a problem [20]. In my research, the two Counties classified as ASAL regions were very hot during the day time and very cold at night. The type of housing in Kajiado County could also fuel the rate of contacting pneumonia because there was no control of cold at night. There was high chance of contacting pneumonia because of this environmental stress. Drought caused less feed and overheating caused stress. The stress reduced the immune system of the goats and enhanced the chances of contacting pneumonia. Rabies was possible because the goats got infected when they were left to graze in the bushes where there were jackals and wild dogs and hyenas that were reservoirs to this disease could spread it. Mashuru division was a migratory cor-

Table 6. Catastrophes in management of goats.

\begin{tabular}{ccc}
\hline Variables & Mean & Std \\
\hline Total drought effects & 1.87 & 1.64 \\
Total disease effects & 0.29 & 0.59 \\
Total rustling effects & 0.08 & 0.28 \\
\hline
\end{tabular}

Table 7. Diseases, parasites and their treatments in Kajiado and Makueni Counties.

\begin{tabular}{|c|c|c|c|c|c|c|}
\hline \multirow{2}{*}{ Factor } & \multicolumn{3}{|c|}{ Kajiado } & \multicolumn{3}{|c|}{ Makueni } \\
\hline & $\mathbf{N}$ & $\%$ respondents & Rank & $\mathbf{N}$ & $\%$ respondents & Rank \\
\hline \multicolumn{7}{|l|}{ Disease } \\
\hline Pneumonia and diarrhoea & 28 & 46.66 & 1 & 31 & 51.66 & 1 \\
\hline Pneumonia & 22 & 37.66 & 2 & 27 & 45.00 & 2 \\
\hline Pneumonia and rabies & 9 & 15.00 & 3 & 0 & 0.00 & 4 \\
\hline Rabies & 1 & 1.66 & 4 & 2 & 3.34 & 3 \\
\hline \multicolumn{7}{|l|}{ Parasites } \\
\hline Tick and fleas & 42 & 70.00 & 1 & 44 & 73.34 & 1 \\
\hline Ticks & 18 & 30.00 & 2 & 16 & 26.66 & 2 \\
\hline \multicolumn{7}{|l|}{ Treatment } \\
\hline Self & 46 & 76.67 & 1 & 46 & 76.67 & 1 \\
\hline Private vet & 14 & 23.33 & 2 & 14 & 23.33 & 2 \\
\hline Govt vet & 4 & 6.67 & 3 & 4 & 6.67 & 3 \\
\hline
\end{tabular}


ridor for animals migrating from Amboseli national park to Maasai-mara national park so that the wild animals and domestic animals shared a range land. The intermingling of domestic animals and the pastoralist nature that existed in the two Counties also contributed greatly to the spread of goats' diseases. Coffey noted similar results that all Kenyan pastoralists face high risk of animal diseases because of aspects such as mobility of the animals based on the livestock production system [18]. Kosgey found that $95 \%$ of households in Kenya reported incidences of diseases in Small holder and pastoralist/extensive farming systems [20].

Ticks and fleas were the most common external parasites the respondents said were menace in the two Counties (Table 7). A total of 18 farmers (30.00\%) claimed that ticks were the greatest problem for their goats while 42 farmers $(70.00 \%)$ claimed that both ticks and fleas were a problem in Kajiado. Of all the farmers interviewed in Makueni 16 farmers (26.67\%) said ticks were the problems while 44 farmers (73.33\%) said that both ticks and fleas were problems. Chi-square test $p>0.05$ showed there was no significant difference in the effects of these parasites. The two Counties were surrounded by game parks and game reserves namely, Amboseli national park, Maasai Mara national park, Tsavo west national park, Tsavo East national park and Chyulu game reserve. The animals in these parks migrated from one park or reserve to the other. During these migratory periods, ticks and fleas were dropped that later climbed the goats reared in these regions. The free ranging feeding system (Table 8) for goats also encouraged the spread of the two parasites. This way it became difficult to break the life cycle of the two parasites because the animals kept visiting the ranging areas. The effects were anaemia in goats and it made it difficult to ignore tick borne diseases even though the respondents never said they were a problem. Coffey noted that goats were susceptible to endo and ecto-parasites with the endo-parasites becoming rapidly resistant to all the available helmintics [18]. The difference between my results and Coffey's result is that in Kajiado and Makueni the farmers neither mentioned endo-parasites as a problem nor did they mentioned resistance to helmintics. It also become difficult to ignore that there were internal parasites because where wild animals grazed together with domestic animals obviously there must have been endo-parasites. Kosgey noted that helminthosis and tick borne diseases were more prevalent among the Kenyan pastoralist farmers [20].

3) Solutions to the factors causing losses of goats

a) Treatment of goats in Kajiado and Makueni

Wherever there are animal problems like diseases or parasites, treatment is important. Chris noted that for success to occur in the production of animals in Turkana district it is good if farmers ensured that animals were in good condition and thus adequate nutrition; protection and timely treatment of diseases and parasites were very essential [15]. Most of the treatments were done by the farmers individually in Kajiado and Makueni Counties (Table 7). Forty six farmers $(76.67 \%)$ in Kajiado treated the animals by themselves, 14 farmers $(23.33 \%)$ used private vets while 4 farmers $(6.67 \%)$ use government veterinarians. A total of 46 farmers $(76.67 \%)$ in Makueni treated the animals individually, 14 farmers (23.33\%) used private veterinarians and 4 farmers (6.67\%) use government veterinarians. The farmers also control ticks and fleas by spraying using acaricides. Most farmers treated the animals themselves because it was either not easy to get a veterinarians or it was expensive to use a veterinary doctor. The report by Spontaneous private veterinary practice in Kenya, 1997 showed that the farmers treated the animals themselves because the veterinarians had unease in accessing the farmers in the remote areas and that it was expensive to travel to these remote areas [25]. Some farmers used traditional medicine (Table 9). This result is the same to Laure who reported that Steven Kiranga Gichanga was a farmer in Mugaari village in Kenya who resorted to used traditional to treat his livestock and did not need a veterinarian [26].

b) Housing type for goats in Kajiado and Makueni Counties

The housing type determines whether goats will suffer from pneumonia, predated on or the success of thieves to steal the goats. Out of the 60 farmers interviewed per County, 39 farmers (64.00\%) in Kajiado (Table 8) and 14 farmers (23.34\%) in Makueni built the houses of goats using wood and thorns. Nineteen farmers $(31.66 \%)$ in Kajiado and 7 farmers (11.66\%) Makueni used wire and thorns while 1 farmer $(1.66 \%)$ in Kajiado and 35 farmers (58.34\%) in Makueni used mud. A few people used wood only. Using wood and thorn or wire and thorn in Kajiado helped to prevent predators and thieves at night and so most farmers resorted to this type of housing. Mashuri is a division in Kajiado and is a migratory corridor for animal migrating between Amboseli national park and Maasai mara national park. This poses high risk to predation because the farmers have homes built in this wild life migratory corridor and hence they used the shown house types. The houses of goats made of mud were the best to prevent thieves at night in Makueni. A chi-square test $\mathrm{p}<0.001$ done revealed that there was a significant difference in the methods of housing. The farmers believed that reinforcing the walls of the goat houses with thorns further reduces the problem of predation from wild animals at night since the two Counties 
Table 8. Management methods in kajiado and makueni.

\begin{tabular}{|c|c|c|c|c|}
\hline \multirow{2}{*}{ Management } & \multicolumn{2}{|l|}{ Kajiado } & \multicolumn{2}{|c|}{ Makueni } \\
\hline & No. of respondents & Rank & No. of respondents & Rank \\
\hline \multicolumn{5}{|l|}{ Feeding method } \\
\hline Free range & 55 & 1 & 12 & 3 \\
\hline Free range and tethering & 5 & 2 & 15 & 2 \\
\hline Tethering & 0 & 3 & 33 & 1 \\
\hline \multicolumn{5}{|l|}{ Housing type } \\
\hline Wood and thorn & 39 & 1 & 14 & 2 \\
\hline Wire and thorn & 19 & 2 & 7 & 3 \\
\hline Mud & 1 & 3 & 35 & 1 \\
\hline Wood & 1 & 3 & 4 & 4 \\
\hline
\end{tabular}

Table 9. The local name, scientific name (in bracket) of the herbs and what they treat.

\begin{tabular}{cc} 
Herb (scientific name) & What it treats \\
\hline Mavuavui (Steganotaenia araliacea) & Pneumonia \\
Uswe (Cissus quaragularis) & Encourage peristalsis/treat stomach problems \\
Mukomole (Tapiphyllum schimanii) & Treats pneumonia \\
Kitanyu kamwene & Normalises blood pressure \\
Kyatha (Synadenium compactum) & Treats lymph problems \\
Mwenzenze (Boscia salicifolia) & Treats pneumonia \\
Muumba (Clerodendrum myriocoides) & Treats malaria \\
Mukenia (Fagara chalybea) & Relieves common cold and treat pneumonia \\
Muvinda vinde (Trimeria glandiflora) & Relieves cough and cleans blood \\
A handful of maize & Removes retained placenta \\
\hline
\end{tabular}

were surrounded by other game parks like Tsavo East and Tsavo West, Amboseli, Maasai Mara and game reserves like Chyulu where animals came from especially during migration and may be when they just crossed the fence to roam about. Lawrence noted that in Laikipia district, farmers use acacia thorn, stone, wooden posts, wire mesh to construct livestock houses so that the domestic animals are not predated on by the wild carnivores at night [27].

4) Water sources

Water was available and reliable according to all the respondents in Kajiado and Makueni Counties. The farmers sourced water from boreholes, dams, piped water, sand wells, government constructed water points, streams and rivers (Table 3$)$. A total of 33 farmers $(55.00 \%)$ get water from government constructed water points, 13 farmers $(21.67 \%)$ get pipeline water and 2 farmer $(3.33 \%)$ get dam water in Kajiado while the majority of the farmers in Makueni get water from streams 19 (31.67), 13 farmers $(21.67 \%)$ get water from the river, 11 farmers $(18.33 \%)$ get water from government constructed water points, 7 farmers $(11.67 \%)$ get piped water, 1 farmers (1.67\%) get dam water and 9 farmers (15.00\%) get well water. When goats met at these water points, they mated and genes were passed from a particular flock in a particular County to another flock in another County. According to Dietz lack of permanent water sources in Kajiado led to construction of several dams and drilling of large number of boreholes. At least 290 boreholes were drilled between 1938-1982 and 43\% of them between 1970-1982. According to Africa-Asia; DRMPA Project, (2012), in the water sector during difficult/ drought periods, the government led the provision of water through water tracking to affected communities [28]. Dietz`s results in Africa-Asia DRMPA, research, are similar to my results.

5) Methods of feeding goats used in Kajiado and Makueni

Goats were majorly grazed by the free ranging system in Kajiado according to the response of 55 (91.66\%) out of 60 farmers in this County. Only 5 farmers $(8.34 \%)$ practiced both free range and tethering in Kajiado. The 
animals were allowed to graze anywhere and without restriction. There was free ranging and tethering systems in Makueni. Out of the 60 farmers, 33 farmers (55.00\%) practiced tethering, 15 farmers (25.00\%) practiced both free range and tethering and 12 farmers $(20.00 \%)$ practice free range (Table 8$)$. Chi-square test analysis $\mathrm{p}<$ 0.001 shows that there was a significant difference in the methods of feeding. During free ranging goats from different flocks and breeds meet and mate; a free ranging male goat can also easily mate with a female goat that is tethered. Almoustapha recorded that in Mali, tethering was the method of feeding used when dealing with few animals during the cropping season and especially the small ruminant [29]. This clearly supports the case feeding method in Makueni.

Food provision to goats during drought was such that most farmers in Kajiado thus; 48 farmers $(80.00 \%)$ cut leaves from up tree to feed their goats during drought, 9 farmers (15\%) collect/pick leaves, cut and buy commercial feeds while 3 farmers (5.00\%) collect/pick leaves. Most farmers in Makueni thus; 23 farmers (38.33\%) cut leaves from up tree to feed their goats during drought, 23 farmer (38.33\%) collect/ pick leaves, cut and buy commercial feeds while 22 farmers (36.67\%) collect/pick and cut leaves, 8 farmers (13.33\%) collect/ pick leaves and 7 farmers (11.67\%) collect, cut and buy commercial.(Table 3). Most farmers did not buy commercial feeds because they said it was expensive. The goats also survived from dry leaves and tree bucks. This was different from Kosgey's results that over $85 \%$ of the farmers bought food supplements for goats whenever there was drought [20]. This finding was the same to Smith and Joshi who found that goats adapt to a wide variety of climatic conditions and survived on browse material not normally utilised by other livestock and were more resistant to drought and adaptable to harsh environment [30] [31]. These findings are also the same to Adugna and Aster who noted that in Ethiopia, when grass become depleted from the grazing land the farmers lop the leaves and branches of trees and feed to their animals [32].

\subsubsection{Breeding Problems in Kajiado and Makueni}

Abortion was the main breeding problem. Fifty four farmers (93.92\%) in Kajiado had the problem of abortion affecting their goats, 3 farmers (5.22\%) said still birth was a problem while 3 farmers (5.22\%) said both abortion and still birth was a problem. Fifty five farmers in Makueni $(95.66 \%)$ had the problem of abortion. These breeding problems were of greatest threats during drought when there was little food for the animals and the female goats aborted or underwent still birth because of stress. These problems reduced the number of kids born and hence the expected increase in population size reduced. Chris found the same results as he reported that in Turkana district which is also an ASAL region that abortion caused the number of off springs born to be limited and production restricted [15].

\subsubsection{Importance of Goats in Kajiado and Makueni}

All the $60(100.00 \%)$ farmers interviewed in Kajiado kept the animals to get money when they sell them and all the farmers used blood from the animals as food, 58 farmers (96.67\%) used goats for meat, 58 farmers (96.67\%) for dowry the bride groom produced the number of goats that the parents of the bride would need, 57 farmers $(95.00 \%)$ for milk, 51 farmers $(85.00 \%)$ use goats during circumcision, 39 farmers $(65.00 \%)$ used the skin when they are slaughtered and 31 farmers (51.67\%) sold their dung as manure to farmers in Makueni who practiced crop production (Table 10). All the farmers interviewed in Makueni kept the animals for cash and dowry. Three goats were used during marriage, two were used to pay dowry while one was slaughtered on the day the bridegroom visited the family of the bride. All the animals for dowry were contributed by the bride groom. The bride groom give goats of any breed, this also result in the introduction of new genes into different flocks depending onto where the goat was sourced, where it is taken to pay the bride price and the type of breed of the goat. Fifty four farmers $(90.00 \%)$ used the manure on their farms for crop production in their farms. Goats were majorly kept for cash both in Kajiado and Makueni. This was used to pay school fees for children and to buy other family belongings. The findings were same to Hefferman and Misturelli who found that the goats were kept for milk, meat [33]. Galvin and Selleh also found that unlike commercial ranches that raised a limited number of animals solely for market off take in confined areas, pastoralists relied on their herds for daily subsistence. Pastoralists diet was milk, meat, blood obtained from their animals and cereals within grown or obtained from trading their animals [34] [35]. Joy noted that in Uganda the hide of a SEA goat gave the best quality leather [36].

\section{Conclusions and Recommendations}

1) The major diseases that hindered the production of goats in Kajiado and Makueni were pneumonia and di- 
Table 10. Importance of goats in Kajiado and Makueni.

\begin{tabular}{ccccc}
\hline Use & \multicolumn{2}{c}{ Kajiado } & \multicolumn{2}{c}{ Makueni } \\
\cline { 2 - 5 } & No. of respondents & Percent & No. of respondents & Percent \\
Cash & 60 & 100.00 & 60 & 100.00 \\
Blood & 60 & 100.00 & 40 & 66.67 \\
Chevon & 58 & 96.67 & 43 & 71.67 \\
Dowry & 58 & 96.67 & 60 & 100.00 \\
Milk & 57 & 95.00 & 42 & 70.00 \\
Circumcision & 51 & 85.00 & 29 & 48.33 \\
Skin & 39 & 65.00 & 26 & 43.33 \\
Manure & 31 & 51.67 & 54 & 90.00 \\
Gift & 30 & 50.00 & 26 & 43.33 \\
Church & 28 & 46.67 & 2 & 3.33 \\
Naming & 3 & 5.00 & 0 & 0.00 \\
\hline
\end{tabular}

arrhoea. Rabies affected the animals in Kajiado and Makueni. The dangerous parasites were ticks and fleas. It is also possible that these two counties are also prone to tick borne diseases that the respondents never talk about. To control pneumonia and problems like diarrhoea, the government should deploy vets to deal with the problem by providing vaccinations against this disease. Rabies could be controlled by discouraging farmers from making homes or grazing in migratory corridors for wild animals. Grazing livestock animals in the wild life corridors also encouraged tick infestations. This would also reduce the level of infection by tick borne diseases.

2) There was a lot of crossbreeding between Galla goat breed and Small East African goats encouraged by factors like shared markets, translocations, drought, rustling, watering points, feeding methods like free range and tethering so that the existing populations were neither pure Galla goats nor pure SEA goats. Diseases, predation, breeding problems like abortion and still birth reduced the level of gene pool.

3) The Galla goats and the SEA goat breeds were kept majorly because they were adapted to the problems like drought and diseases like pneumonia in the two counties. The two breeds survived well in ASAL regions even if they were attacked by drought or dangerous diseases like pneumonia. A cross breed between the two breeds would not suffer if similar problems of drought or diseases occurred.

4) Farmers in Kajiado majored in livestock production as a major land use and an investment. Crop production was practiced in few areas like in Kimana and Loitokitok. The farmers in Makueni practiced mixed farming. The system in Makueni ensured that there was no total loss when the animals were attacked by calamities. The farmers in Kajiado kept many animals so that in case of calamity, some remained and continued to express the tolerant genes and also to save in the livelihood.

5) Water was available except that the farmers bought it expensively. Animals died due to lack of enough feed during drought. Farmers should be encouraged to plant artificial plants like Leucaena leucocephala which were very leafy, even if they were to be managed under irrigation. Secondly, they should have grazing reserves well fenced to keep off even wild animals; these could help to provide food during drought.

6) Ethno medicine should not be ignored because not everywhere will prefer agro vets to buy drugs or vet officers to treat the animals to be found. The herbalists who knew good drugs that could treat various diseases should be encouraged to treat the goats to reduce the levels of deaths experienced.

\section{Acknowledgements}

I would like to acknowledge Dr. J. O. Jung'a under whose supervision this study was a success. His personal interest in this study, encouragements, guidance, patience and kindness made it possible for me to complete it. I highly appreciate him in times of difficulties, his remarks made life bearable. He showed great wisdom and experience in this work.

My second supervisor, Prof. M. S. Badamana who was also key in giving directions in this research. He showed great interest in this research and write up. I am grateful to him for making me feel at ease while doing this research. His patience and concern to finish this research is highly appreciated in my pursuit of a higher de- 
gree.

I am also greatly indebted to Dr. Amimo who assisted very much in analysis of this research. I highly appreciate his kindness and efforts to make sure this research become a success.

My lecturers, colleagues and students also deserve special mention. I am specifically indebted to Mr B.O. Inyangala, Dr. Felix Matura, Mr. Charles Odhong, for their technical and moral support.

\section{References}

[1] Abate, A., Wanyoike, M.M., Badamana, M.S. and Abate, A.N. (1989) Towards Improving Animal Production in the Rangelands. Proceedings of the 16th Grassland Congress, 2, 1613.

[2] NAFIS (2009) Local Breeds. The Small East African Goat. http://www.go.ke/livestock/dairygoat-production/breeds/

[3] Young African Express (2011) Raising Livestock in Dry Lands. Volume 6, No. 3.

[4] Devendra, C. and McLeroy, G.B. (1982) Goats and Sheep Production in the Tropics. Longman Group, London.

[5] Kisiangani, E. (2008) Conservation of Indigenous Livestock Breeds. Practical Action East Africa.

[6] Hassen, H., Baum, M., Rischkowsky, B. and Tibbo, M. (2012) Phenotypic Characterization of Ethiopian Indigenous Goat Populations. African Journal of Biotechnology, 11, 13838-13846.

[7] Counties of Kenya-Makueni County (2014).

[8] Counties of Kenya-Kajiado County (2014).

[9] Bernsten, R.H. and Jacobs, A.H. (1983) Socio-Economic Aspects of Range Research in Kenya: A Plan for Reaching the Ultimate Target Groups. Ministry of Livestock Development, Nairobi, 112 p.

[10] Snedecor, G.W. and Cochran, W.G. (1967) Statistical Methods. 6th Edition, The Iowa State University Press, Ames.

[11] Berhanu, T., Thiengtham, J., Tudsri, S., Abebe, G., Tera, A. and Prasanpanich, S. (2012) Purpose of Keeping Goats, Breed Preference and Selection Criteria in Pastoral and Agro-Pastoral Districts of South Omo Zone. Livestock Research for Rural Development, 24.

[12] Stroebel, A. (2004) Socio-Economic Complexities of Small Holder Resource-Poor Ruminant Livestock Production Systems in Sub-Saharan Africa. Master's Thesis, University of the Free State, Bloemfontein.

[13] Oluka, J., Ssewannyana, E., Oweyesigire, B. and Esenu, B. (2004) Small Stock and Women in Livestock Production in the Teso Farming System Region of Mombasa.

[14] Ole Kwallah, S. (1992) Cultural Aspect in Relation Education: Low Participation Rate Early Drop out and Moranism among Maasai Pastoralists in Kajiado. Proceedings of the 3rd Conference on the Future of Maasai Pastoralists in Kajiado District, 23-26 August 1992.

[15] Imana, C.A. and Greyling, J. (2008) Goat Rearing as a Livelihood Strategy of Turkana Pastoralists in North and West Kenya. Master's Thesis, University of the Free State, Bloemfontein.

[16] Grandin, B.E. (1989) Land Tenure, Sub-Division and Residential Changes on Maasai Group Ranch Development. Economic Anthropology, 2, 9-13.

[17] Mbolu, K. (2011) Long Rain Assessment in Makueni District.

[18] Coffey, L., Hale, M. and Wells, A. (2004) Goat Sustainable Production Overview. National Centre for Appropriate Technology, United States Department of Agriculture, 1-24.

[19] Ahuya, C.O., Okeyo, A.M. and Hendy, C. (2001) Consortium Project on: Community Based Goat Breeding Improvement. Department of Animal Health, University of Nairobi, Nairobi.

[20] Kosgey, I.S., Rowland, G.J., Van Arendonk, J.A.M. and Baker, R.L. (2008) Small Ruminant Production in the Tropics. Study of Small Holder and Pastoral Extensive Farming Systems in Kenya. Small Ruminant Research, 77, 11-24.

[21] Galvin, K.A., Coppock, D.L., Leslie, P.W. and Fratkin, E. (1994) Diet Nutrition and the Pastoral Strategy. In: Fratkin, E., Galvin, K.A. and Roth, E.A., Eds., African Pastoralist Systems: An Integrated Approach, Dietrich Reimer Verlag $\mathrm{GmbH}$, Berlin, 113-132.

[22] Semakula, J., Mutetika, D., Kugonza, D.R. and Mpairwe, D. (2010) Comparison of Breeding Systems by Small Holder Goat Keepers in the Humid; Sub-Humid and Semi-Arid Ecological Zones of Uganda. Global Veterinarian, 4, $283-291$.

[23] Lukhele, M. and Ramsey, A. (2002) Review of the National Goat Development Strategy for South Africa. Department of Agriculture, University of Pretoria, Pretoria.

[24] Conroy, C. and Rangnekar, D.V. (2000) Constraints Facing Goat Keepers in Semi-Arid India. Proceeding of the 7th International Conference on Goats, Tours, 15-18 May 2000.

[25] Spontaneous Private Veterinary Practice in Kenya, 1997.

[26] Gilbert, L. (2013) When Family Farmers Lead Their Own Development. 
http://www.agriculturesnetwork.org/magazines/global/family-farming/people-led-development

[27] Frank, L.G., Woodroffe, R. and Ogada, M.O. (2005) People and Predators in Laikipia District in Kenya. Cambridge University Press, Cambridge.

[28] Diertz (2012) Africa-Asia Drought Risk Management Peer Assistance Project Enhancing Asia-Africa Corporation and Promoting Integrated Drought Risk Reduction and Climate Change Adaptation.

[29] Almoustapha Coulibaly (2006) Mali’s Country Pasture/Forage Resource Profiles. FAO, Rome.

[30] Smith, T., Godfrey, S.H., Butterfly, P.J. and Owen, E. (2002) Helping Smallstock Keepers Enhance Their Livelihood. Improving Management of Small Holder Owned Sheep and Goats by Utilising Local Resources. Proceeding of the Working on Enhancing the Contribution of Small Livestock to the Livelihood of Resource for Poor Communities, Masaka, 8-10 January 2002, 69-75.

[31] Joshi, L., Conroy, C., Thaku, Y.A. and Vander, M.L. (2003) Easing Seasonal Food Scarcity for Goats in Semi-Arid India through a Process of Participatory Research. Proceedings of the Third DFID Livestock Production Programme Link Project (R7798) Workshop for Small Ruminant Keepers, Embu, 4-7 February 2003, 14-28.

[32] Tolera, A. and Abebe, A. (2007) Livestock Production in Pastoral and Agro-Pastoral Production Systems of Southern Ethiopia. Livestock Research for Rural Development, 19.

[33] Hefferman, C. (2000) Livestock and the Poor: Issues in Poverty-Focused Livestock Development. University of Reading, Reading.

[34] Galvin, K.A. (1992) Nutritional Ecology of Pastoralists in Dry Tropical Africa. American Journal of Human Biology, 4, 209-221. http://dx.doi.org/10.1002/ajhb.1310040206

[35] Sellen, D.W. (1996) Nutritional Status of Sub-Saharan African Pastoralists: A Review of the Literature. Nomadic People, 39, 107-139.

[36] Joy (2013) Goat Development Programme. Local Types of Ugandan Goats.

[37] Draft Guidelines on Phenotypic Characterization of Animal Genetic Resources. Commission on Genetic Resources for Food and Agriculture (CGRFA), Thirteenth Regular Session, 18-22 July 2011, Rome.

\section{Abbreviations and Acronyms}

ASAL: Arid and Semi-Arid Land.

CGRFA: Commission on Genetic Resource for Food and Agriculture.

CV: Coefficient of Variation.

DRMPA: Drought Risk Management Peer Assistance Project.

GIS: Geographical Information System.

GPS: Global Positioning System.

Hrs: Hours

$\mathrm{Km}^{2}$ : Square Kilometers

NAFIS: National Farmers Information Service.

N: Sample size.

SD/std: Standard Deviation.

SEA: Small East African.

SAS: Statistical Package for Analysis. 


\section{Appendices}

\section{Appendix I: Questionnaire}

\section{Preliminary Information}

\begin{tabular}{|l|l|}
\hline Farmer Name & \\
\hline Enumerator name & \\
\hline County & \\
\hline Division & \\
\hline Location & \\
\hline Sub-location & \\
\hline Village & \\
\hline GPRS (GPS ) Reading & \\
\hline Date & \\
\hline
\end{tabular}

\section{General Questions}

\begin{tabular}{|c|c|c|c|c|}
\hline $\begin{array}{c}\text { Sex of the } \\
\text { interviewee }\end{array}$ & $\begin{array}{c}\text { Number of } \\
\text { family members }\end{array}$ & $\begin{array}{c}\text { Schooling } \\
\text { (code) of the interviewee }\end{array}$ & $\begin{array}{c}\text { Main activities } \\
\text { of interviewee }\end{array}$ & $\begin{array}{c}\text { Hrs/day spent } \\
\text { on activities }\end{array}$ \\
\hline Male & & & & \\
\hline Female & & & \\
\hline
\end{tabular}

Schooling: [1. None 2. Pri school 3. Secondary school 4. Post-secondary school]

Farming type.

[1. Pastoralists 2. Semi-commercial 3. Commercial 4. Mixed farming]

Ownership of the flock

[1. Father 2. Mother 3. Children 4. Other, Who?]

Who manages the flock

[1. Father 2. Mother 3. Children 4. Other, Who?]

Roles during management

\section{Goat Management}

1) Flock structure

Number of goats in farm/household

What breed(s) do you keep?

\begin{tabular}{|l|l|}
\hline Small East African goat & \\
\hline Galla & \\
\hline Other (specify) & Number \\
\hline Structure & \\
\hline Female kids & \\
\hline Male kids & \\
\hline Weaned female & \\
\hline Mature female & \\
\hline Weaned male & \\
\hline Intact male weaners 1 testicle & \\
\hline Castrate weaners & \\
\hline Intact male weaners both testicle & \\
\hline Mature female & \\
\hline Intact male kids 1 testicle & \\
\hline Intact male kids both testicles & \\
\hline
\end{tabular}




\section{O. G. Otieno et al.}

\section{Continue}

\begin{tabular}{|l|l|}
\hline Intact male adults 1 testicle & \\
\hline Intact male adults both testicle & \\
\hline Castrate males adults & \\
\hline Mature male & \\
\hline Breeding females & \\
\hline Breeding buck & \\
\hline Total & \\
\hline
\end{tabular}

2) Selection of breed

Criteria used for the selection of the best animal for phenotypic and genotypic characterization.

\begin{tabular}{|l|l|}
\hline Factors & Tick appropriately \\
\hline adaptability & \\
\hline age at maturity & \\
\hline body size & \\
\hline conception rate & \\
\hline disease resistance & \\
\hline Docile & \\
\hline drought resistance & \\
\hline fecundity & \\
\hline growth rate & \\
\hline heat tolerance & \\
\hline high market value & \\
\hline milk production & \\
\hline physical appearance & \\
\hline posture and gait & \\
\hline Prolificacy & \\
\hline skin colour & \\
\hline
\end{tabular}

II. If you keep more than one breed what is the advantage of doing this?.

3) Purpose of keeping goats

What role(s) do goats play in your farm/community? (Tick one or more)

\begin{tabular}{|l|l|l|}
\hline & Tick & Rank \\
\hline Chevon & & \\
\hline Milk & & \\
\hline Manure & & \\
\hline Blood & & \\
\hline Skin & & \\
\hline Mohair & & \\
\hline Cashmere & & \\
\hline Cash from sales & & \\
\hline Investment & & \\
\hline Dowry & & \\
\hline Ceremonies & & \\
\hline Cultural & & \\
\hline
\end{tabular}


Others (specify)

Where do you graze your animals

Who owns the land.

(individual, community)

Do you market?

Name the market place

4) Catastrophes

What are the major catastrophes that occur within your area?

\begin{tabular}{|l|l|l|}
\hline Factor & Tick appropriately & Number of animals lost \\
\hline Droughts & & \\
\hline Disease outbreaks & & \\
\hline Rustling & & \\
\hline Other (explain) & & \\
\hline
\end{tabular}

What is the number of animals lost in the recent catastrophe? (Fill as appropriate)

\begin{tabular}{|l|l|l|l|l|l|}
\hline & Breed & Kids & Weaned & Does & Males \\
\hline Drought & & & & & \\
\hline Disease outbreak & & & & & \\
\hline Rustling & & & & & \\
\hline Other & & & & & \\
\hline
\end{tabular}

Diseases/parasites

Do you have any problems with parasites? Yes

...No.

Do you have any problems with parasites? Yes ...No.

Parasite control method

\begin{tabular}{|l|l|}
\hline 1. & \\
\hline 2. & \\
\hline 3. & \\
\hline 4. & \\
\hline 5. & \\
\hline
\end{tabular}

Do you ever recruit help from outside to control the parasites?

Yes ............................................

List the common diseases that occur in goats within your farm/household (i.e. from symptoms that are seen by the farmer in his animals)

\begin{tabular}{|l|l|l|}
\hline Disease & Treatment given & No treatment given \\
\hline & & \\
\hline & & \\
\hline & & \\
\hline & & \\
\hline & & \\
\hline & & \\
\hline & & \\
\hline & & \\
\hline
\end{tabular}

Who normally treat your animals?

\begin{tabular}{|l|l|}
\hline Government vet & \\
\hline Private vet & \\
\hline Veterinary drug supplier & \\
\hline Extensive service & \\
\hline Yourself & \\
\hline None & \\
\hline
\end{tabular}


Other (specify).

How often do you treat your animals

Drought

Is water always available for household use?

Yes No

\begin{tabular}{|l|l|l|}
\hline Water for animal & Dry season & Rainy season \\
\hline How frequently do you give your goats water? & & \\
[1.Once a day 2.Twice a day 3.Thrice a day & & \\
4.Throughout day 5.Other, what?] & & \\
\hline Water source & & \\
[1.Borehole 2.Dam 3.Well 4.River 5.Spring 6.Stream & & \\
7.Natural occasions 8.Constructed water points 9.Rainwater harvesting & & \\
10. Pipeline 11.Other, what?] & & \\
\hline Is this water source reliable? Yes or No & & \\
\hline Do you have to pay for the water? Yes or No & & \\
\hline
\end{tabular}

When did you have the worst drought in the last five years?

What goat breed survived the long dry period than others?

Died. Survived.

Why did this breed survive better than you think?

What handling practices are used during drought?

Are some animals prioritised with feeds and water during dry periods?

What type of housing is used for the goat?

[1.Wire + thorn 2. Wood + thorn 3.Mud 4.Wood]

5) Feeding

Is the feed for goats based on pasture? Yes.

No

Is any supplement food given to the goats?

What else:

What grazing methods do you use for your goats?

(1. Free range 2. Tethering 3. Free range and tethering)

f. Breeding

i. Who make decisions on breeding?

ii. Which breeding system(s) do you use?

Pure breeding.

Crossbreeding

Why do you use this system?

Practice cross-breeding and they gave the following selection criteria.

\begin{tabular}{|l|l|}
\hline Cross breeding criteria & \\
\hline Body size & \\
\hline Early maturity & \\
\hline Growth rate & \\
\hline Market value & \\
\hline Meat quality & \\
\hline Milk production & \\
\hline
\end{tabular}

Mating system

Which mating systems do you use?

Natural controlled.

Natural uncontrolled. 
Artificial insemination

Reasons for choosing this mating system

kidding seasons etc)

Method for controlling mating.

1. Apron 2. Castrate 3. Relocate males 4. Apron + Castrate 5. Castrate +Relocate)

What is the average age at first parturition?

How many years do you keep selected animals?

Male:

Female:

When does mating occur?

When does kidding occur?

When are the kids weaned?

What factors do you consider when selecting a male for breeding?.

What factors do you consider when selecting a female for breeding?

Breeding problems

\begin{tabular}{|l|l|}
\hline Reported problem & Tick \\
\hline abortion & \\
\hline deformed kids & \\
\hline still birth & \\
\hline diseases & \\
\hline Abortion and still birth & \\
\hline
\end{tabular}

Do you milk your goats? Yes.

No

Other aspects of indigenous knowledge

What traditional herb do you use when goat is sick?

Herb.

What it treats.

Adopted from Commission on genetic resources for food and agriculture (CGRFA) [37]. 